مجلة جامعة سبها للعلوم البحتة والتطبيقية

Sebha University Journal of Pure \& Applied Sciences

Journal homepage: www.sebhau.edu.ly/journal/index.php/jopas

\title{
Histological changes in female mice kidneys as a result of Valproic acid drug treatment
}

\author{
* Omelaz A. M. Elturshani ${ }^{\mathrm{a}}$, Khalida R. Al-Sarraj ${ }^{\mathrm{b}}$, Tarek A. Guseibat $^{\mathrm{b}}$, El-nagi O. M. El-nagaz ${ }^{\mathrm{b}}$, Amal El-Tarhouni ${ }^{\mathrm{b}}$ \\ ${ }^{a}$ Medical Laboratory Department, Faculty of Medical Technology, Benghazi, Libya \\ ${ }^{\mathrm{b}}$ Zoology Departmen, Faculty of Science, Benghazi University, Benghazi, Libya
}

\section{Keywords:}

Cellular infiltration

Cell necrosis

Hydropic degeneration

Oedema

Valproic acid

\begin{abstract}
A B S T R A C T
Valproic acid is a broad spectrum anti- convulsant drug, established as a long - term treatment for epilepsy and has toxic effect on kidney tissues. This study aimed to investigate the histological changes that may occur in the kidney in association with prolonged administration and overdose treatment of valproic acid. 35 albino mice were used, they were divided into four groups, group(I) included 5 animals and served as control group, group(II) included 10 animals and given progressive doses of valproic acid for ten weeks, starting with $(15 \mathrm{mg} / \mathrm{kg} /$ day $)$ as minimum recommended dose and ending with $(60 \mathrm{mg} / \mathrm{kg} /$ day $)$ as maximum recommended dose, group(III) included 10 animals and received an overdose $(120 \mathrm{mg} / \mathrm{kg} /$ day) for one week, group(IV) included 10 animals and treated exactly as group(II) then the animals were left for recovery for three weeks. The animals were sacrificed at the end of each period and the kidney tissue was excised. The drug induced many histological changes in kidney tissues, including inflammatory cellular infiltration, cell necrosis, cloudy swelling, hydropic degeneration, hemorrhage areas, oedema, and collagen deposition. The study concluded that valproic acid has multiple toxic effects on kidney tissues as far as the histological studies concerned and the effects were dependent on the dose and on the duration of treatment. Incomplete recovery was recorded after discontinuation of the drug.
\end{abstract}

\section{التغيرات النسيجية في كلى اناث الفئران الناتجة عن المعالجة بعقارحامض الفالبرويك}

*ام العز عبدالجليل الطرشاني و خالدة رشيد السراج² وطارق عبدالله قصيبات² و الناجي عمر مسعود النقاز² امال ابراهيم الترهوني2

$$
\begin{aligned}
& 1 \text { فسم المختبرات الطبية، كلية التقنية الطبية، جامعة بنغازي، ليبيا } \\
& \text { 2 فسم علم الحيوان، كلية العلوم، جامعة بنغازي، ليبيا }
\end{aligned}
$$

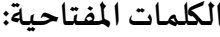

الخلايا الالتهابية

تنخر خلوي

التحلل المائي

الاستستقاء

حامض الفالبرويك
حامض الفالبرويك هو عقار مضياد للصرع واسع الانتشار يستخدم في علاج الصرع على المدى الطويل وله تأثير سام على انسجة الكلية، هدفت هذه الدراسة لمعرفة مدى تأثير هذا العقار على انسجة الكلية باستخدام الجرعات على المدى البعيد والجرعة القصوى. حيث استعملت في هذه الدراسة 35 من اناث الفئران قسمت الى 4 مجاميع الاولى (الضابطة) واشتملت 5 حيوانات، الثانية (المعاملة) واشتملت على 10 حيوانات في كل منهات واستقبلت جميعها جرعات تصاعدية يومية من العقار تبدأ ب 15 ملجم/كجم وتنتهي ب 60 ملجم/كجم لمدة

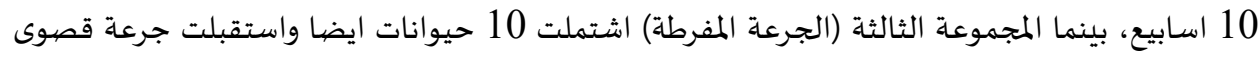
120 ملجم/ كجم لمدة اسبوع، المجموعة الرابعة (التعافي) اشتملت 10 حيوانات وعوملت مثل المجموعة الثانية من حيث الجرعة ثم اوقفت الجرعة وتركت للتعافي مدة 3 اسابيع. مع انتهاء التجريع تم تشريح الفئران واستخلاص النسيج الكلوي، أحدث العقار العديد من التغيرات النسيجية اشتملت على ظهور الخلايا الالتهابية، تنخر خلوي، تحلل مائي، ظهور المناطق النزفية، الاستسقاء وترسبات الياف الكولاجين. من ذلك نستنتج ان

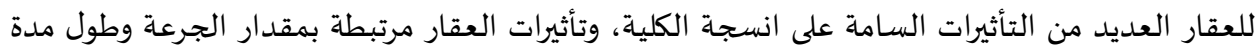

$$
\text { التجريع ، مع عدم وجود تعافي كامل بعد مرور } 3 \text { اسابيع من ايقاف التجريع. }
$$

*Corresponding author:

E-mail addresses: Azaa.Ahmad1983@gmail.com, (K. R. Al-Sarraj) khalida229@yahoo.com, (T. A. Guseibat) tarek.guseibat@uob.edu.ly, (E. O. M. El-nagaz) Angel007ly@yahoo.com, (A. El-Tarhouni) eltarhouni80@gmil.com 


\section{Introduction:}

Valproic acid is a broad-spectrum anti- convulsant drug [1], established as a long - term treatment for epilepsy [2], marketed in Europe in 1968 and in the United States 10 years later [3]. Widely used in treatment of various seizure disorders and some psychiatric condition $[4,5]$. Some of anti-convulsant drugs that are widely used such as valproic acid can cause adverse renal effects and their use are usually associated with dilatations in distal and proximal tubules $[6,7]$.

Valproic acid affects the kidney functions after prolonged treatment, a significant increase was observed in the catalytic activities of gamma - glutamyltransferase and alkaline phosphatase in urine [8]. Scientists have shown that the dilatations in the distal tubules in cortex and some infiltrations around the glomeruli [7]. Other Scientists have found that sodium valproate leads to adverse renal effects such as Fanconi syndrome and interstitial nephritis in a Japanese girl with epilepsy [9]. A case of acute interstitial nephritis caused by sodium valproate, have also been demonstrated by name the author [10]. The study demonstrated that renal biopsy revealed interstitial nephritis in the renal tubular basement membrane [11]. Long-term use of valproic acid leads to multiple organ damage, including tubulointerstitial nephritis [12]. Other researchers found that the use of valproic acid only cause degenerative changes especially in renal glomerular basal membrane and foot process, but when they used both valproic

acid and folic acid or valproic acid and vitamin E showed relatively normal ultra-structure [13]. Others demonstrated that alternations in human renal functions such as increased in urine volume and $\mathrm{PH}$ were associated with valproic acid treatment $[8,14]$.

\section{Materials and methods:}

\subsection{Experimental animals:}

35 adult female albino mice weighing $22-26 \mathrm{~g}$ were used in this experiment and were housed at room temperature.

\subsection{Experimental design:}

Mice were divided into the following groups:

Group (I) ( Control): this group included 5 animals, which received normal saline orally.

Group (II): included 10 animals and received therapeutic dose of valproic acid. The dose was adjusted for mice according to the formula of $[15,16]$ and was found to be $15 \mathrm{mg} / \mathrm{kg} /$ day. The drug was administered orally, using the original gastric tube with a syringe needle head [17]. Animals in this group were given a daily therapeutic dose of valproic acid, starting with $15 \mathrm{mg} / \mathrm{kg} /$ day and increased gradually to end with $60 \mathrm{mg} / \mathrm{kg} / \mathrm{day}$ as following: (15 $\mathrm{mg} / \mathrm{kg} / \mathrm{day}$ for one week - $30 \mathrm{mg} / \mathrm{kg} / \mathrm{day}$ for one week - 45 $\mathrm{mg} / \mathrm{kg} / \mathrm{day}$ for two weeks $-60 \mathrm{mg} / \mathrm{kg} / \mathrm{day}$ for six weeks ).

Group ( III ): This group included 10 animals , and received daily overdose of valproic acid (twice the maximum recommended dose) $(120 \mathrm{mg} / \mathrm{kg} /$ day ) for one week .

Group ( IV ): The animals of this group were treated exactly as group ( II ), then the drug intake was stopped and the animals were left for recovery for three weeks .

\subsection{Histological examination:}

Animals of all the above groups were sacrificed following mild diethyl ether anesthesia and the kidney tissue was excised (from each animal rapidly) and immediately fixed in $10 \%$ neutral phosphatebuffer formalin and processed for paraffin method [18]. And then stained by different stains as following:

I-Hematoxylin and Eosin stains $[19,18]$ : to demonstrate the general histological structure of kidney.

II-Masson's Technique[19]:to demonstrate collagen fibers.

After staining the specimens were examined under a CARL ZEISS research microscope and photographed with a digital camera attached.

\section{Results: \\ Group I ( Control):}

Hematoxyline \& Eosin stained sections of kidney cortex taken from control group, showed the normal morphological appearance of the kidney cortex with normal renal corpuscle and renal tubules (fig.1), as well as corticomedullary junction (fig .2). Regarding the Masson's trichrome stained sections, normal distribution of fine collagen fibers surrounding renal tubules and renal corpuscle were observed (fig.3).

Group II (10 weeks of treatment):

Stained sections of Hematoxylin \& Eosin showed heavy focal areas and diffused inflammatory cellular infiltrate in the cortex (fig.4), some associated with blood vessels and some between renal tubules (fig.5), as well as in between corticomedullary junction (fig.6). The glomeruli also showed heavy cellular infiltration (fig.7). Extensive cloudy swelling with hemorrhage areas were also observed in renal tubules of corticomedullary junction (fig.8). Necrosis of renal tubules was also observed. The cortex region also showed many hemorrhage areas (fig.9). The stained sections with Masson's trichrome revealed many areas of heavy deposition of collagen fibers with heavy cellular infiltrates between kidney tubules (fig.10).

\section{Group III (Overdose treatment):}

Sections stained with Hematoxylin \& Eosin showed extensive focal areas of heavy cellular infiltrates, most of them were associated with blood vessels in the cortex (fig.11). The glomeruli also showed extensive cellular infiltrates (fig.12), as well as in the corticomedullary junction (fig.13). In addition some areas of the cortex showed moderate oedema associated with cellular infiltrates (fig .14). Severe hemorrhage areas extended between renal tubules of the cortex (fig.15), as well as within the Bowman's space of renal corpuscle were also seen (fig.16). The renal tubules of corticomedullary junction showed many prominent changes i.e. some tubules showed extensive hydropic degeneration and cloudy swelling (fig.17), other tubules showed complete degeneration with diffused inflammatory cells (fig.18). Regarding Masson's trichrome stain, many focal areas showed heavy deposition of collagen fibers between renal tubules in kidney cortex (fig.19), as well as surrounding many renal corpuscle (fig.20).

\section{Group IV( Recovery):}

Stained sections with hematoxylin and Eosin showed persistent of heavy inflammatory cells associated with some glomeruli (fig .21), As well as persistent of hydropic degeneration in some renal tubules in corticomedullary junction. Some areas of the cortex still showed mild deposition of collagen fibers between renal tubules as showed by Masson's trichrome stain (fig.22).

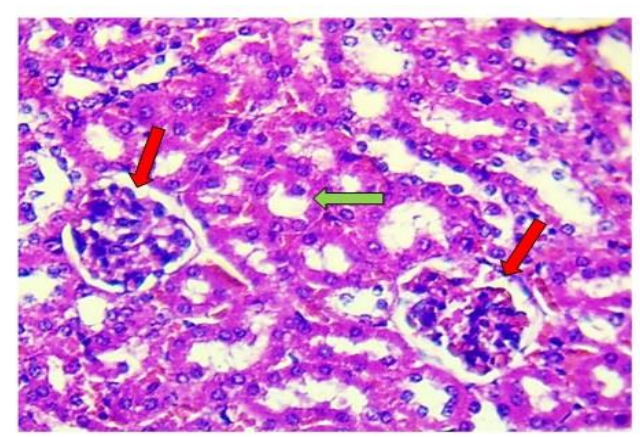

(Fig.1): Micrograph of normal kidney (control group) showing normal renal corpuscles (red) \& renal tubules (green) (H\&E X 400). 


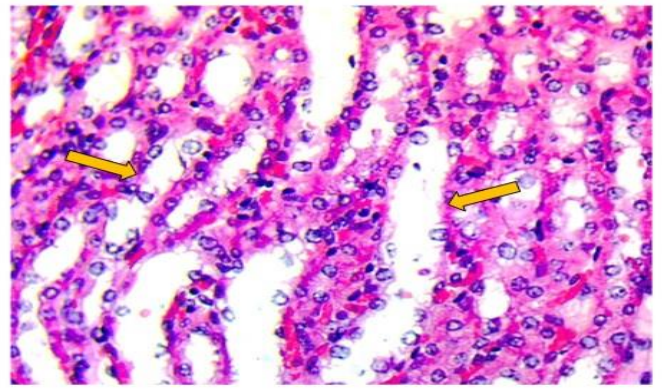

(Fig.2): Section of corticomedullary junction (control group) showing normal renal tubules (yellow) (H \& E X400).

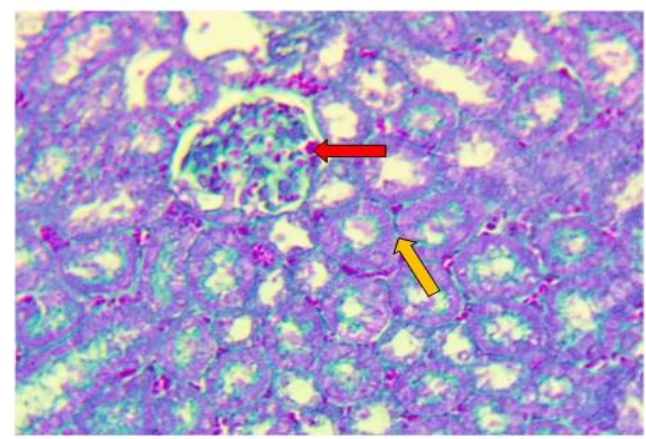

(Fig.3): Micrograph of kidney cortex (control group)showing normal distribution of collagen fibres surrounding renal corpuscle (red) \& renal tubules ( yellow) (Massons' trichrome X 400).

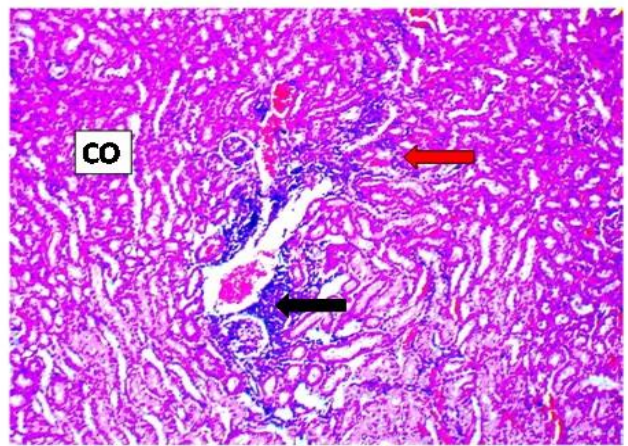

(Fig.4): Micrograph of a section in renal cortex $(\mathbf{C O})$ (after ten weeks ) showing heavy focal areas of cellular infiltrates ( black) $\&$ diffused inflammatory cells ( red) ( H\&E X 100).

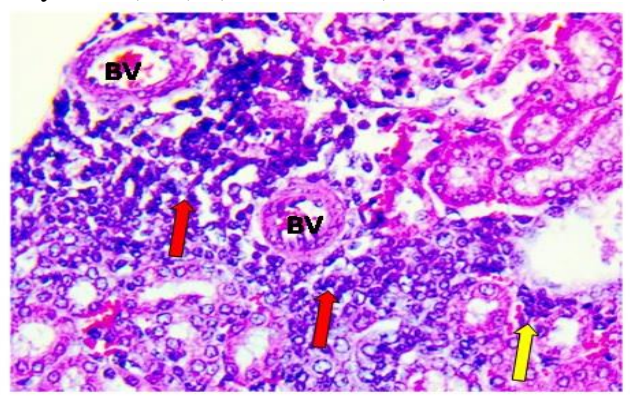

(Fig.5): Micrograph of the renal cortex (after ten weeks) showing extensive cellular infiltrates associated with blood vessels $(\mathbf{B V})$ red) \& renal tubules (yellow) (H\&E X 400).

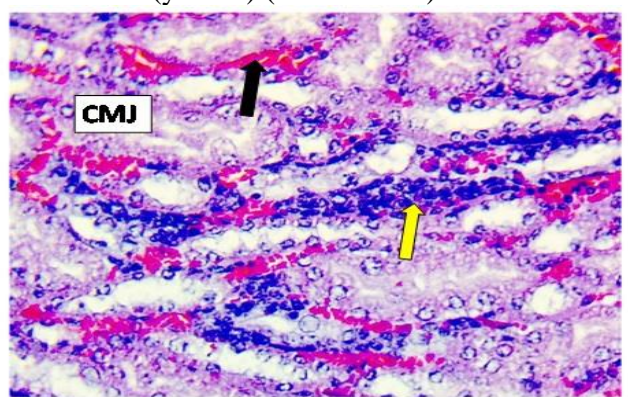

(Fig.6): Section after (ten weeks) in cortico- medullary junction (CMJ) showing heavy cellular Infiltrates between renal tubules (yellow) with hemorrahage areas (black) (H\&E X 400).

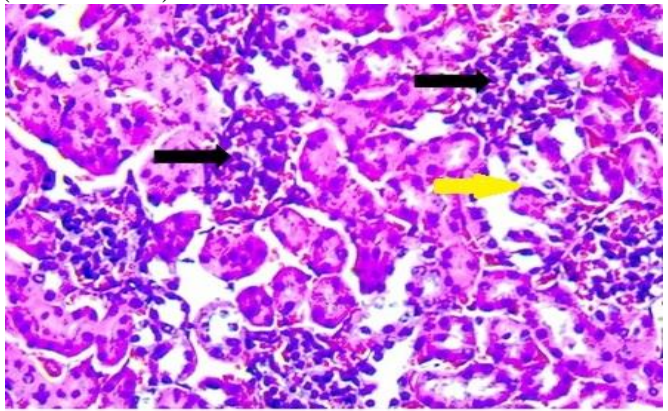

(Fig. 7): Micrograph of renal cortex (after ten weeks ) showing many glomeruli with heavy cellular infiltrates (black) \& necrotic renal tubules (yellow)( H\&E X 400).

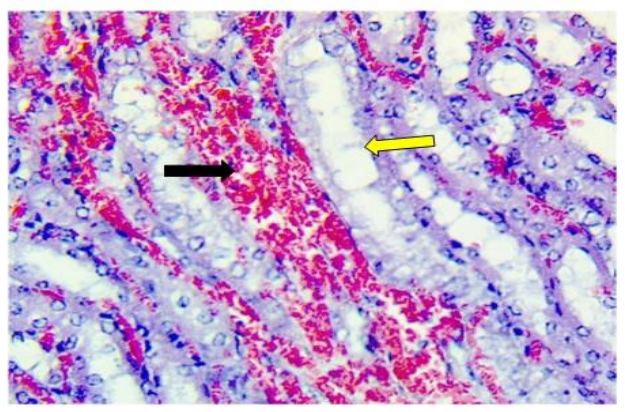

(Fig. 8): section of cortico-medullary junction ( ten weeks ) showing extensive cloudy swelling (yellow) with extensive hemorrhage areas ( black) (H\&E X 400).

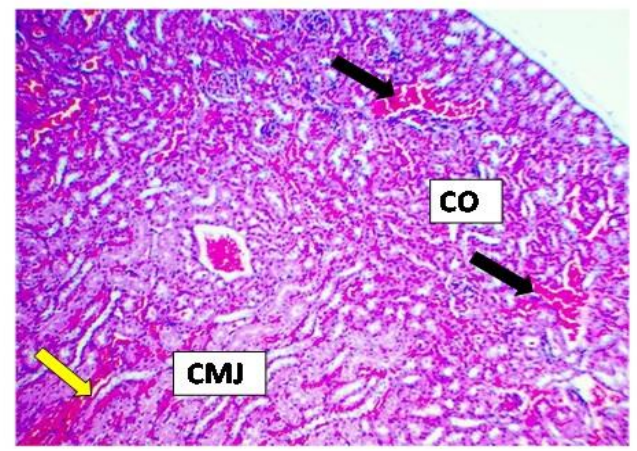

(Fig. 9): Micrograph of section ( ten weeks) showing extensive hemorrhage areas in cortex $(\mathbf{C O})$ ( black) \& in $(\mathbf{C M J})$ yellow) (H\&E X 100).(

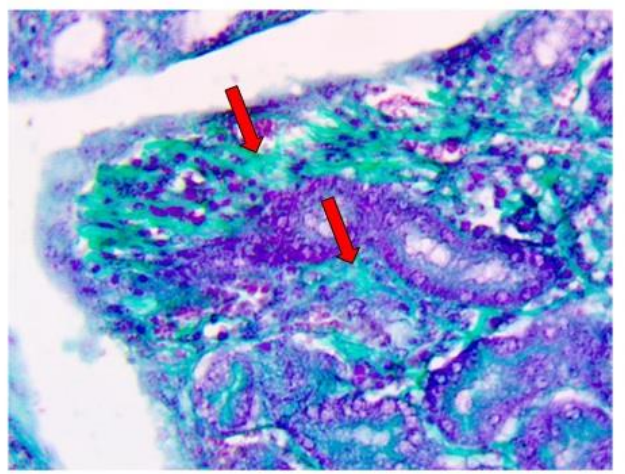

(Fig. 10): Micrograph of kidney cortex (ten weeks) showing heavy deposition of collagen fibers between renal tubules (red) (Massons' trichrome X 400). 


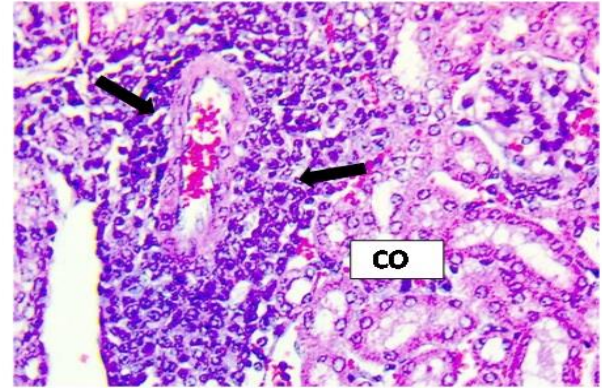

(Fig. 11): Micrograph of renal cortex (CO) (overdose group) showing extensive focal areas of heavy cellular infiltrates with blood vessels (black) H\&E X 400).

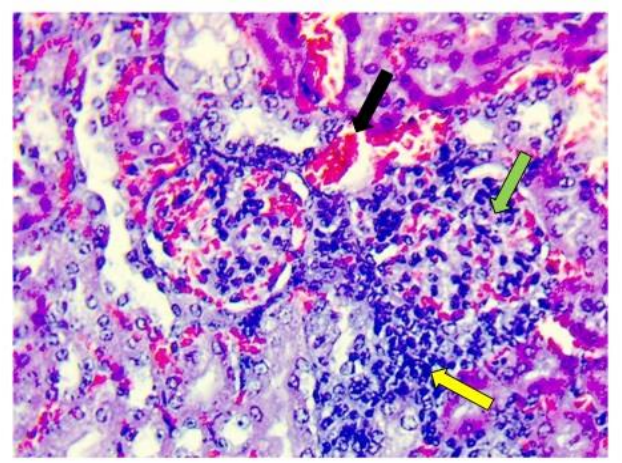

(Fig. 12): Micrograph of renal cortex (CO) overdose group) showing extensive cellular infiltrates within the glomeruli ( green) \& around it (yellow) with hemorrahge areas (black) ( H\&E X 400).

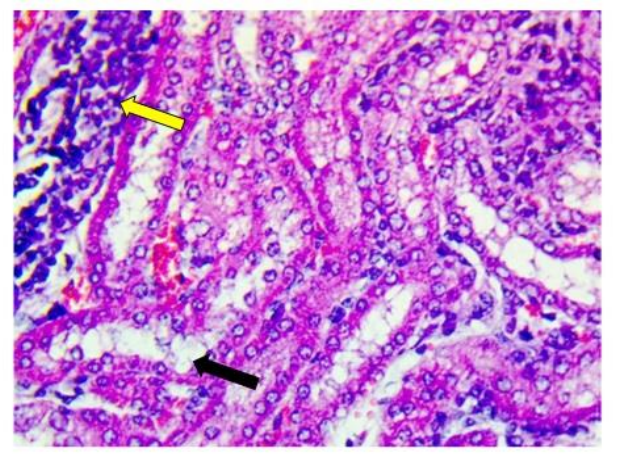

(Fig. 13): This section after (overdose treatment) in corticomedullary junction showing heavy cellular infiltrates between renal tubules (yellow) \& extensive hydropic degeneration (black)( H\&E X 400).

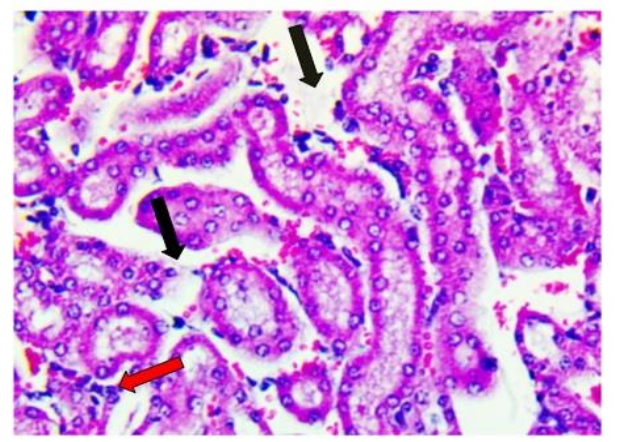

(Fig. 14): Micrograph of a section after (overdose treatment) in renal cortex showing interstitial oedema (black) \& diffused inflammatory cells (red)

(H\&E X400).

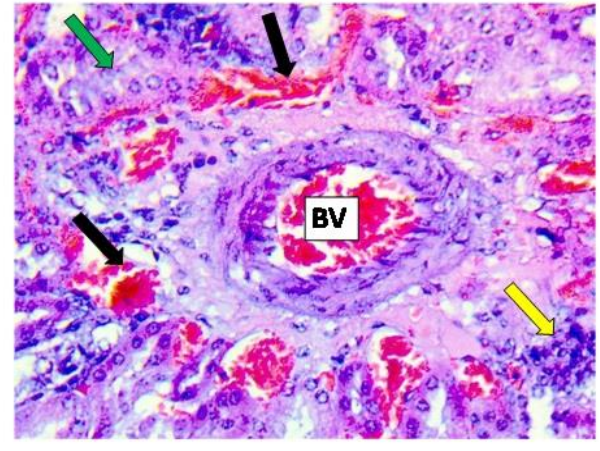

(Fig. 15): Micrograph after (overdose treatment) showing severe hemorrhage areas (black) extended between renal tubules of cortex (green), blood vessel (BV) \& cellular infiltration (yellow) (H\&E X 400).

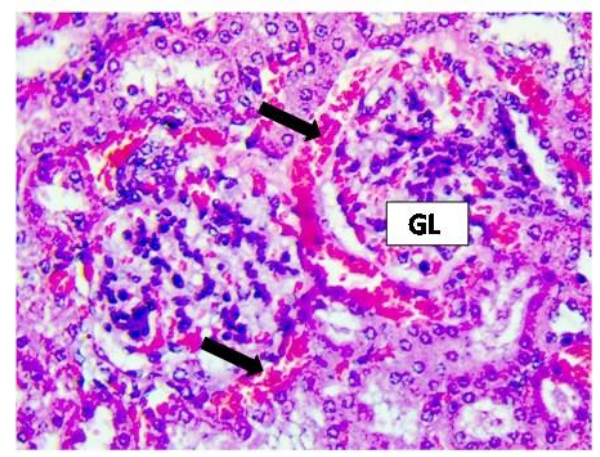

(Fig. 16): Micrograph of a section in renal cortex (overdose group) showing severe hemorrhage within the Bowmans' space of two renal corpuscles \& glomeruli (GL) (black) (H\&E X 400).

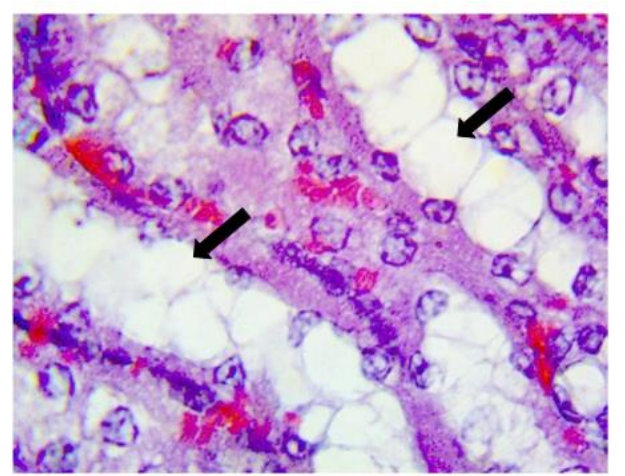

(Fig. 17): Higher magnification of (CMJ) (overdose group) showing extensive hydropic degeneration \& cloudy swelling (black)( H\&E X 1000).

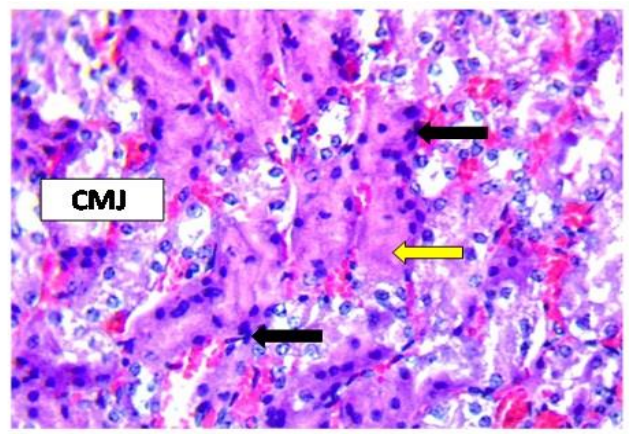

(Fig. 18): Micrograph of a section in(CMJ) (overdose group) showing complete degeneration of renal tubules (yellow) \& with inflammatory cells(black) (H\&E X 400). 


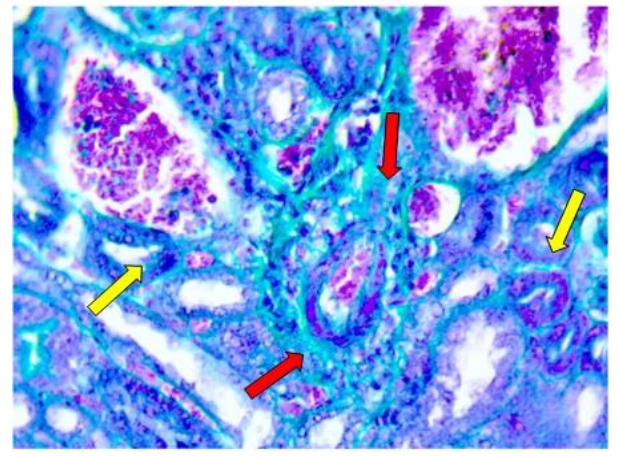

(Fig. 19): Micrograph of a section in renal cortex (overdose group) showing many focal areas of heavy deposition of collagen fibers (red) between renal tubules (yellow) (Massons' trichrome X 400).

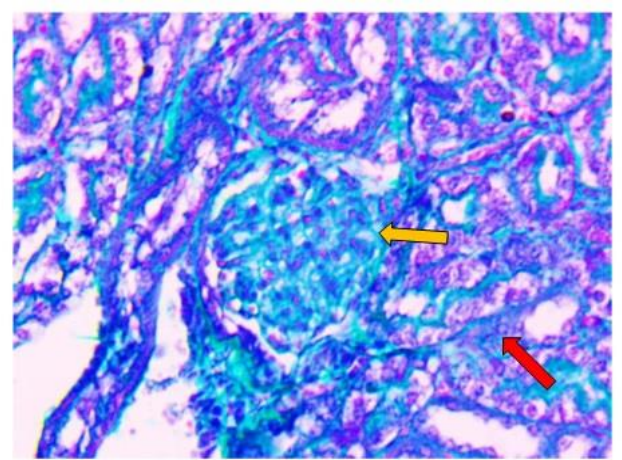

(Fig. 20): Micrograph of a section in renal cortex (overdose group) showing heavy deposition of collagen fibers between renal tubules (red) \& surrounding renal corpuscles (yellow) (Massons' trichrome X 400).

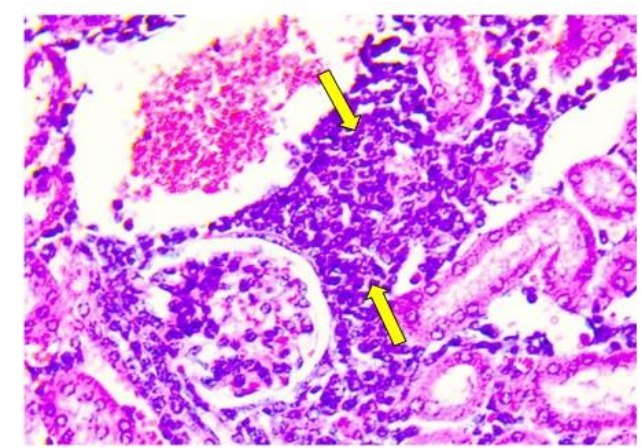

(Fig. 21): Micrograph of a section in renal cortex (recovery group) showing persistent of heavy inflammatory cells surrounding the renal corpuscle \& renal tubules (yellow) ( H\&E X 400).

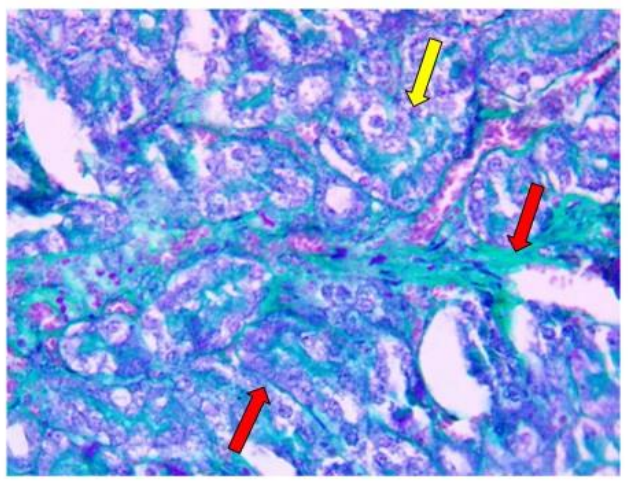

(Fig. 22): This section of a renal cortex (recovery group) showing mild deposition of collagen fibers (red) between renal tubules (yellow) (Massons' trichrome X 400).

\section{Discussion:}

In the present study the animals that received normal saline were used as a control of the experiment, and showed a typical morphological and histological picture of normal kidney [20,21]. The term interstitial nephritis, tubulointerstitial disease are frequently used to describe those situations in which the predominant morphological changes that occur in the renal interstitium (i.e. inflammatory cells, oedema, or fibrotic changes) and renal tubules (a variable degree of tubular damage, such as necrosis) [22]. All animals that were treated with an overdose of valproic acid for one week only died. This result is in accordance with that of many investigators which demonstrated that cerebral oedema, respiratory depression, multiorgan failure, abnormal heart rhythms, hemorrhagic pancreatitis and coma are associated with overdose treatment, and may even lead to death $[23,24,25,26,27$ and 1$]$.

The interstitial cellular infiltrates were of variable density, whereas the inflammatory cells were predominantly lymphocyte, but, neutrophilis and macrophages were also present. The later cells are commonly found in association with the process of chronic inflammation $[28,29]$. However the presence of interstitial cellular infiltrates may be related to the direct effect of one or more of valproic acid metabolites on the lining epithelium of the renal tubules with secondary activation of lymphocytes.

This study has shown, that as a result of the longer duration of treatment there was a steady increase of tubulointerstitial injury, such changes were found in association with some drug and heavy metals which induce direct tubulointerstitial nephritis [30].

The hemorrhage areas ranging from few to moderate, extensive and severe in animals that were treated for ten weeks and the overdosed animals. Hemorrhage may result from trauma, chronic disease process affecting the wall vessels such as atherosclerosis and acute process affecting the vessels wall such as bacterial toxin, drug toxin, and many other factors. Hemorrhage associated with nephritis have been reported by [30], they demonstrated that congestion of blood capillary with interstitial hemorrhage may be due to the rupture of the endothelial wall of greatly dilated capillaries.

The renal tubules in the cortex and corticomedullary junction which showed tubular dilatation and vacuolization (i.e. cloudy swelling and hydropic degeneration) was found to be associated with early injury [28] and it is reversible and probably has no influence on renal function. Researchers have demonstrated that the cytoplasm of some or many of the proximal tubules epithelial cells may be filled with fine vacuoles in acute tubular necrosis or in patients treated with hypertonic solution such as dextran or mannitol [30], they demonstrated that the vacuolization of the cells is due to dilatation and swelling of the endoplasmic reticulum and mitochondria which was described as a cloudy swelling [30]. With further swelling of organelles the cells become waterlogged the true vacuoles appear in the cytoplasm, the cells are said to exhibit hydropic degeneration [30].

The interstitial tissue of animals after ten weeks of treatment and overdose group showed mild to moderates oedema with mild inflammatory cells. Oedema means an abnormal accumulation of fluid in the interstitim with cellular infiltration, resulting in separation of renal tubules from each other. This happens when small blood vessels in renal tissue leak fluid, or when the blood loses a protein called albumin. The protein albumin keeps fluid in the blood vessels [28,31]. In this study the flattened lining tubular cells with small dense nuclei, may indicate cellular necrosis and ultimately tubular necrosis. our result are in accordance with that of $[31,32]$ which have demonstrated that tubular necrosis is usually associated with cellular necrosis.

The heavy collagen deposition was observed after ten weeks of treatment and in the overdose group, was in accordance with that found by [33] who showed that the most common disturbance in extracellular matrix resulting from new metabolic disturbance and the use of pharmaceuticals, this represent the major lesion of renal disease (fibrosis) and is characterized by deposition of matrix components particularly the interstitial collagen. The marked increase of collagen fibers may be attributed to the stimulation of fibroblastic potential of interstitial fibroblast - like cells (type 1 interstitial cells), resulting in increased synthesis of collagen fibers. It has been shown that type 1 cells quite likely are responsible for the secretion of small bundles of collagen and reticular fibers that 
normally present in the interstitium $[34,35]$. These changes have also shown to be associated with diabetes mellitus [32].

\section{Conclusion:}

As a result of our study it can be concluded that valproic acid has multiple toxic effects on kidney tissues as far as the histological studies concerned and the effects were dependent on the dose and on the duration of treatment. The interstitial tissue, the renal tubules in cortex, the corticomedullary junction and the glomeruli, exhibit the most important changes in all groups. Regarding the recovery group, the discontinuation of drug for three weeks result in an incomplete recovery. The animals models have provided a basis for further studies in human.

\section{References :}

[1]- Gris, M., Zahir, S., Penaloza , A . and Lheureux , P .(2005). Carnitine in The Treatment of Valproic Acid - Induced Toxicity - What is the evidence ? .Clin . Toxic . 9 (5) : $431-440$.

[2]- Shang - long, Y., Shi - ying, Y., San - peng , X ., Ai - ling, S., $\mathrm{Ze}-$ jun, D ., Yuan - xu, J . and You, S.(2010). Valproic Acid Attenuates The Multiple - Organ Dysfunction in Rats Model of Septic Shock. Chin. Med . J . 123 ( 19 ) : $2682-2687$.

[3]- Gilman, A . G., Rall , T . W ., Nies, A . S. and Taylor, P .( 1991 ). The Pharmacological Basis of Therapeutic. International edition . pp . 436 - 439. Macillan Publishing Company, Singapore.

[4]- Jamsheer, A ., Materna - Kiryluk , A . and Latos - Bielenska, A .( 2008 ). Valproic Acid and Pregnancy : Clinical Presentation of Three Cases with Valproate Embryopathy. Arch . Perinatal . Med . 14 ( 1 ) : $57-60$

[5]- Yerby , M . S .( 2003 ). Management Issues for Women with Epilepsy. Neural Tube Defect and Folic Acid Supplementation . Neurol . 61 (2): 23 - 26.

[6]- Jabeal, I . A . and El - Bauomy , A . M . (1998 ). Principles of Pharmacology. 1st ed ., pp . 131 - 137 . El - tahady University.

[7]- Dincer , T . , Bayazit , V ., Cetinkaya , C . and Cimbiz , A .(2005 ). Effect of Valproate and Clonazepam on Kidney Tissue of Female Rats . J. Med. Sci . 5 ( 2) : 70 - 74 .

[8]- Cepelak, I. , Rekic , B ., Juretic , D . and Mandusic, A .( 1995 ). Effect of Sodium Valproate on Renal Brush - Border Enzyme in Rats . J . Clin . Chem . Clin . Biochem . 33(10) : $673-677$.

[9]- Yoshikawa, H ., Watanabe, T . and Abe , T . (2002 ). TubuloInterstitial Nephritis Caused by Sodium Valproate. Brain Development . 24(2): $102-105$.

[10]- Kamper , A . , Martuseviciene , G . and Horn , T. (2006 ) . A Severe Case of Interstitial Nephritis Caused by Sodium Valproate . Ugeskr Laeger. 168 ( 43 ): 29 - 30.

[11]- Chiang, H . and Lin, C .( 1988 ). Sodium Valproate - Induced Interstitial Nephritis . Nephron . 48 (1) : 6- 43.

[12]- Pages , M ., Baldet, P ., Droz, D ., Moragues , H . and Canaud, B . (2007) . Collapsing Focal Segmental Glomerulosclerosis as A Possible Complication of Valproic Acid . South A fri. Med . J . 97 ( 6 ) : $: 388-390$.

[13]- Nasir, Y . , Akkus, M ., Nergiz , Y . and Aktas , A. (2010 ). The Effect of Valproic Acid on Renal Corpuscle of Pregnant Rats and Protective Role of Folic Acid and Vitamin E . African Journal of Biotechnology . 9 ( 34 ) : $5605-5610$.

[14]- Pauwels, M . , Geers, C ., Van Beneden, K .,Verbeelen, D . Van Grunsven , L . and Van den , C. (2011). Valproic Acid Attenuates Proteinuria and Kidney Injury . J. A. S . N. 22(10): $1863-1875$.

[15]- Pagat, G . E . and Barnus, J . H . (1964). Evaluation of Drug Activities Pharmacyometerics, Vol . I, by Laurance, O . R . and Bachanch, A . L ., Academic Press, New York .

[16]- Tvrzicka , E . , Cvrekova , E ., Maca , B . and Jiraskova, M .(1995) . The Effect of Ibuprofen on The Composition of Tissue Lipids in an Experiment . Cas . Lek . Cesk .134 ( 14 ) : $450-455$.

[17]- Baker, H . J . , Lindsey, J . R . and Weisbroth , S . H .(1980). Laboratory Rat .2nd ed ., Vol . I , pp . 128 - 335, and Vol . II , pp . $145-155$. Academic Press Inc, New York .
[18]- Preece, A . H .(1972) . A Manual for Histologic Technicians . 4th ed ., pp . 227 - 321 . Little , Brown and Company, Boston .

[19]- Bancroft , J . D . and Cook , H . C . (1994). Manual of Histological Techniques and Their Diagnostic Application .2nd ed., pp. 42- 53 . Churchill Livingstone, London .

[20]- Ross, M . H . , Kaye, G . I . and Pawlino , W .(2006). " Histology ; A Text and Atlas with Cell and Molecular Biology $"$. 4th ed .pp . $603-626$. Philadelphia, New York .

[21]- Fawcett , D . W. and Bloom , W . (2004). " Bloom and Fawcett" A Text Book of Histology . 12th ed ., pp . $728-755$. Chapman and Hall, New York.

[22]- Churg , J . , Catran , R . S . , Sinniah , R . , Sakaguchi , H . and Sabin , L . H . (1984). Renal Disease Classification and Atlas of Tubulointerstitial Disease . PP . 221 . Igakushoin, New York .

[23]- Jeske , A . H .(2008). Mosby's Dental Drug Reference .8th ed ., pp . 1237 . Mosby, United States .

[24]- Khoo , S . H . and Leyland, M . J . (1992 ) . Cerebral Edema Following Acute Sodium Valproate Overdose . Clin. Toxic .30( 2 ) : $209-214$.

[25]- Sztajnkrycer , M . D .(2003). Valproic Acid Toxicity : Overview and Management . J. Toxicol . Clin . 41( 4 ) : 215 .

[26]- Lau , F . L ., Tse , M . L . and Chan , Y . C .(2007). Two Cases of Valproic Acid Poisoning Treated With L- Carnitine . Hun . Exp . Toxic . 26 ( 12 ) : $967-969$

[27]- Zilker, T ., Gerbitz , K . D ., Steimer , W ., Gempel , K . Felgenhauer, N . and Eyer , F .(2005). Acute Valproate Poisoning : Pharmacokinetics, Alteration in Fatty Acid Metabolism . J. Clin .Psychopharmaco . 25 ( 4 ) : 376 - 380 .

[28]- Stevens , A ., Lowe , J . S . and Young, B .(2002). "Wheater's basic histopathology " A Color Atlas and Text . 4th ed ., pp . 21 - 115. Churchill Livingstone, London .

[29]- Robbins , M . D ., Stanley, L ., Kumar , M . D ., and Cotron, M . D . (2004) . Pathology Basis and Disease . 5th ed ., W . B . Saunder, London .

[30]- Porter, K . A . , Pugh , R . C . B . and Ansell , I . D .(1992). The Kidney . "The Urinary Tract" . Vol . 8, 3rd ed ., pp . $204-$ 207 . Churchill Living Stone, London .

[31]- Dische, F . E .(1995). Renal Pathology . 2nd ed . , pp . 93 - 94. Oxford University Press Inc, New York .

[32]- Kumar , V . , Abbas , A . and Fausto , N .(2005). Robbin's and Cotron Pathology and Basis Disease . 17th ed ., pp . 21, 37 , 103,967 .Chapman and Hall, New York .

[33]- Haverty , T ., Neilson, E . G . and Kuncio , G . S .(1991). Mechanism of Tubulointerstitial Fibrosis. Kidney International . (39) : $550-556$.

[34]- Bohman, S . O . (1974) . The Ultra-structure of The Rat Renal Medulla as Observed After Improved Fixation Methods . J . Ultrastru . Res . 47(3) : 329-360 .

[35]- Martinez - Hernandez , A ., Gag , S . , and Miller, E . J .(1982). Ultra-structure localization of Type $\mathrm{V}$ collagen in The Rat Kidney . J . C . Bio . Cell . 92 (2) : $343-349$. 